\title{
Sustainable Markets: Case Study Of Toyota Motor Sales, U.S.A., Inc.
}

\author{
Dean R. Manna, Ph.D., Robert Morris University, USA \\ Gayle Marco, Ph.D., Robert Morris University, USA \\ Brittany Lynn Khalil (student), Robert Morris University, USA \\ Sara Meier (student), Robert Morris University, USA
}

\begin{abstract}
"The traditional definition of sustainability calls for policies and strategies that meet society's present needs without compromising the ability of future generations to meet their own needs (1)." Sustainability is a concern in private and public sectors all over the world; it is an issue that resonates with people in all age ranges, income levels, and geographic locations. The main idea of sustainability is "reduce, reuse, and recycle." People and organizations alike must consider every possible effect from the decisions they make in regards to the environment. With over 600,000,000 passenger cars on the road in the world, and over 50,000,000 passenger cars built each year, it is imperative that automakers make sustainable decisions (2). It is not just the large number of vehicles in the world that is cause for concern, but the immense amount of resources needed to manufacture, transport, and fuel them. Automakers must consider the impact that each car has during every stage of its life cycle, in addition to their responsibility to society (in terms of the environment, education, and safety) and the impact of their suppliers. This case study is designed to discuss the background of Toyota and highlight the company's current actions in regard to sustainable marketing; a comparison will also be made to the sustainable efforts of Honda and Subaru.
\end{abstract}

Keywords: sustainability; automakers; Toyota; Honda; Subaru; green; green operations; green manufacturing

\section{INTRODUCTION TO THE HISTORY OF TOYOTA MOTOR SALES, U.S.A.}

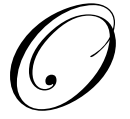

n October 31, 1957 Toyota Motor Sales, U.S.A. Inc. was established. Their headquarters were established in an old Rambler dealership in Hollywood, California. They began selling cars in 1958, and they sold 288 vehicles that year; 287 Toyopet Crown sedans and one Land Cruiser. Soon it was discovered that the Toyopet, despite its sturdy build and quality features, was underpowered and overpriced for the American market. The Toyopet was discontinued in 1961. The Land Cruiser carried Toyota's sales in the United States until 1965 when the Toyota Corona arrived. The Corona was specifically designed for the American drivers. It had a powerful engine, factory installed air conditioning, and an automatic transmission. The sale of the Corona helped to increase Toyota's sales in America threefold in 1966 to more than 20,000 units.

By July 1967, Toyota had become the third best selling import brand in the United States. The Corolla was introduced in 1968, and like the Corona, was a huge hit with the American drivers. The "Corolla has since become the world's all-time best-selling passenger car, with 27 million sold in more than 140 countries (3). Toyota's onemillionth vehicle was sold in 1972. Toyota then surpassed Volkswagen as America's number one selling import brand by the end of 1975. "Three years later, in 1978, Toyota won the "Import Triple Crown" by leading all import brands in sales of cars, trucks, and total vehicles (4)."

As Toyota celebrated its $25^{\text {th }}$ anniversary in American in 1982, it opened a new national headquarters complex that it still occupies today in Torrance, California. In 1986, it became the first import automaker to sell more than one million vehicles in America in a single year. This year also marked the company's debut as an U.S. manufacturer, with the introduction of the first car Toyota built on American soil. The car was a white Corolla 
FX16 which was produced on October 7, 1986, at the New United Motor Manufacturing, Inc. plant, a joint venture with General Motors. Since then, Toyota has established many other vehicle and parts plants in North America.

By 2010, Toyota will have the annual capacity to build about 2.2 million cars and trucks and 1.45 million engines in 15 plants across North America, including the States of California, Kentucky, Indiana, West Virginia, Alabama, Tennessee, Texas, Missouri and Mississippi. As Toyota's presence grew in America, the company sought to gain greater involvement in the community nationwide. So, to commemorate the company's $30^{\text {th }}$ anniversary in America in 1987, Toyota established the Toyota USA Foundation with a $\$ 10$ million endowment and a mission to make Toyota a leading corporate citizen. In 1989, Toyota established their luxury line with the debut of the Lexus LS 400 and the ES 250. Highly acclaimed cars and exceptional customer service quickly became the trademark of Lexus. In 1991, Lexus earned the title of No. 1 luxury import in the United States, surpassing both Mercedes Benz and BMW. By the end of 2000, following its tag line, "The Relentless Pursuit of Perfection," Lexus edged Mercedes Benz by 423 units to become the top-selling luxury brand in the United States, a position it has held for nine years running. That year, the brand also dominated three independent J. D. Power and Associates quality surveys, being named top nameplate in Customer Satisfaction, Sales Satisfaction and Initial Quality.

Toyota continued its strong growth through the 1990s. A highpoint came in December 1997 when the Toyota Camry first earned the title of No. 1 selling passenger car in America. Toyota also launched its first fullsized pickup, the Tundra, in 1998. Toyota marked the start of the new millennium with the launch of the Prius, the world's first mass-produced gas/electric hybrid car. Prius, which in Latin means "to go before," was revolutionary, featuring an EPA-estimated fuel economy rating of 45-city/51 highway and ultra-clean tailpipe emissions that were 90 percent less in smog-forming gases than conventional cars at the time.

May 2001 marked the incorporation of Toyota Motor Sales de Mexico, Toyota's new sales and marketing subsidiary in Mexico. By the end of the year, Toyota had grown to become the third best selling automotive brand in the United States, surpassing Dodge with best-ever sales of 1,741,254 vehicles. In December of 2002, Toyota delivered its first two zero emission, market ready hydrogen fuel cell vehicles to customers in California for real world testing. The next year, Toyota's new, breakthrough hybrid technology, "Hybrid Synergy Drive" debuted in an all new 2004 Prius.

Toyota's growth in America continued in 2003 when Toyota launched Scion as its third line of vehicles. The Scion line features three modestly priced but feature-rich vehicles brought to market by most Toyota dealers under an innovative, youth-oriented marketing program. Scion was a success and in 2004, Toyota's U.S. sales topped two million vehicles per year for the first time.

In 2005, Toyota continued expanding its environmentally advanced lineup with the introduction of the world's first luxury hybrid, the Lexus RX 400h, and a hybrid option for the Toyota Highlander. Toyota added a hybrid option to its popular Camry sedan in 2006 and began building it in the United States at its massive Kentucky plant. The company also opened up its $10^{\text {th }}$ U.S. plant in San Antonio, Texas to build full-size pickups. In addition, the company launched the FJ Cruiser with a design that harkens to the early years of the rugged Land Cruiser, the only vehicle Toyota has continuously sold throughout its entire 50-year history in America. As a Result, sales surged to more than 2.5 million for the first time and Toyota established itself as the third best-selling automotive company in the United States.

During 2007, its $50^{\text {th }}$ year in America, Toyota introduced its largest pickup truck ever, the rugged 2008 Toyota Tundra, as well as the second generation of its iconic Scion xB urban utility vehicle and the world's first V8 hybrid, the Lexus LS 600h.

As a result of an economic recession, Toyota's sales were down in 2008, but the Toyotas brand outsold Chevrolet to become the No. 1 selling automotive brand in America and Camry retained its crown as the No. 1 selling car in the nation for the $11^{\text {th }}$ time in 12 years. Toyota also passed General Motors in global sales to become the world's largest automaker for the first time in history. In 2009, Toyota is prepared to launch two all-new gas/electric hybrids, the third generation Prius, with an estimated EPA fuel economy rating of 50 miles per gallon in combined driving, and the first, dedicated hybrid from Lexus, the HS 250h. 


\section{SUSTAINABLE CHANGES}

Toyota has been heavily involved in the implementation of sustainability throughout the company. They have made huge improvements in regards to protecting the environment and their consumer, and they are still striving towards higher goals in terms of sustainability.

The following outlines some of the sustainable changes that they have made over the past few years.

\section{SUSTAINABLE LEADERSHIP CHANGES}

In a major move in an attempt to become more sustainable, they initiated a drastic organizational structure change. On June 23, 2006, Toyota Motor Company released the announcement that they were making changes in terms of their board of directors and organizational structure. As a result of the changes, TMC now has one chairman, one vice chairman, 1 president, 8 executive vice presidents, 13 senior managing directors, 1 honorary chairman, 1 senior advisor, 1 member of the board, 7 auditors and 49 managing officers for a total of 82 executives.

\section{Sustainable Organizational Structural Changes}

Toyota also made some of the following sustainable changes to its organizational structure:

\section{Domestic Sales Operations Group and Overseas Planning Operations Group}

- The Domestic Sales Operations Group and the Overseas Planning Operations Group have been reorganized.

- $\quad$ Sales and planning functions, which were divided by region, i.e., domestic and overseas, have been integrated.

\begin{tabular}{|l|l|}
\hline \multicolumn{1}{|c|}{ After Changes } & \multicolumn{1}{c|}{ Before Changes } \\
\hline Global Planning Operations Group (new) & Domestic Sales Operations Group \\
\hline - Global Planning Div. (new) & Domestic Sales Planning Div. \\
\hline - LEXUS Product \& Marketing Planning Div. (new) & $\begin{array}{l}\text { Oversees Planning Operations Group (BR Overseas LEXUS Sales } \\
\text { \& Marketing Planning Dept.) }\end{array}$ \\
\hline Japan Sales Operations Group (reorganized) & Overseas Planning Div. \\
\hline - Japan Sales Planning Div. (reorganized) & Overseas Marketing Div. (partially) \\
\hline Global Planning Operations Group (new) & Overseas Planning Operations Group \\
\hline - Global Marketing Div. (name changed) & -Overseas Marketing Div. \\
\hline
\end{tabular}

Purpose: As a global business management function of Toyota's global headquarters, to allow close coordination between TMC and various regions, including Japan, and to implement the "most suitable growth strategy from a global perspective" through product, price and supply-and-demand.

\section{Government \& Public Affairs Group/General Administration \& Human Resources Group}

- The transfer of some divisions/departments of the General Administration \& Human Resource Group to the Government \& Public Affairs Group, have taken place.

\begin{tabular}{|l|l|}
\hline \multicolumn{1}{|c|}{ After Changes } & \multicolumn{1}{c|}{ Before Changes } \\
\hline Government \& Public Affairs Group & General Administration \& Human Resources Group \\
\hline - Public Affairs Administration Dept. (transfer) & -Public Affairs Administration Dept. \\
\hline - Tokyo Secretarial Div. (transfer) & - Tokyo Secretarial Div. \\
\hline - Tokyo General Administration Div. (transfer) & - Tokyo General Administration Div. \\
\hline
\end{tabular}


Purpose: To optimize the structured organization and distribution of human resources by consolidating the divisions and departments relevant to government $\&$ public affairs.

\section{Production Control \& Logistics Group}

- $\quad$ The name of the Production Control \& Logistics Group has changed.

\begin{tabular}{|c|c|}
\hline \multicolumn{1}{|c|}{ After Change } & \multicolumn{1}{c|}{ Before Change } \\
\hline Strategic Production Planning Group (name changed) & Production Control \& Logistics Group \\
\hline
\end{tabular}

Purpose: To create a name that reflects a strengthened stance toward planning that considers the actual situation of global production activities.

\section{Housing Group (Housing Company)}

- $\quad$ The name of the Housing Group (Housing Company) has changed.

\begin{tabular}{|l|l|}
\hline \multicolumn{1}{|c|}{ After Change } & \multicolumn{1}{c|}{ Before Change } \\
\hline Housing Group (name changed) & Housing Group (Housing Company) \\
\hline
\end{tabular}

Purpose: To reflect the achievement of the original objective to reinforce operational structures through the introduction of the "company" system.

Divisions/Departments not belonging to a group; Asia, Oceania \& Middle East Operations Group; China Operations Group

- $\quad$ The transfer of some divisions/departments to relevant groups.

\begin{tabular}{|l|l|}
\hline \multicolumn{1}{|c|}{ After Changes } & \multicolumn{1}{c|}{ Before Changes } \\
\hline Asia, Oceania \& Middle East Operations Group & Divisions/departments not belonging to a Group \\
\hline - Taiwan Office (transfer) & - Taiwan Office \\
\hline China Operations Group & \\
\hline - China Office (transfer) & - China Office \\
\hline
\end{tabular}

Purpose: To clarify the chain of command and to optimize the structural organization and distribution of human resources. ${ }^{1}$

\section{SUSTAINABLE OPERATIONAL CHANGES}

\section{Greener Operations (5)}

In 2009, Toyota commissioned the MV Auriga Leader, the world's first solar-powered pure car carrier, to exclusively transport Toyota, Lexus and Scion vehicles. The vessel's 328 solar panels provide up to $40 \mathrm{kwH}$, decreasing demand on the auxiliary engines.

In 2009, Lexus Technical Training Center in Miramar, FL received Gold LEED certification. Between 2001 and 2008 they reduced energy consumption at the North American non-manufacturing facilities by over $26 \%$, exceeding the initial 2011 target.

1 As a result of the above changes, the number of divisions has increased from 228 to 229 . 
The second largest single-roof solar power installation in North America, a 2.3 megawatt solar array system, began operation in 2008 at Toyota's North American Parts Center California (NAPCC) in Ontario, California.

In 2007, Pat Lobb Toyota of McKinney, TX became the first automotive dealership in the nation to receive LEED Certification (Silver). Since then, three additional Toyota dealerships have received LEED Certification with multiple other dealerships in the planning process.

In 2005, the Portland Vehicle Distribution Center received Gold LEED Certification. The site is powered by $100 \%$ wind energy and $99 \%$ of construction waste was diverted from landfill.

In 2003, Toyota unveiled an expansion of their sales headquarters. The complex was the largest ever to receive a Gold Level Certification from the U.S. Green Building Council's Leadership in Energy and Environmental Design (LEED) Green Building rating system.

They provide more than 1,750 Toyota, Lexus and Scion dealers in North American with resources to help manage service-related waste streams and comply with regulatory requirements.

\section{Greener Manufacturing (5)}

They have reduced their water usage per vehicle by $20 \%$ since 2003 and continue efforts to improve water management. Through their aggressive use of waste management and recycling, the North American plants have reduced their landfill waste by $96 \%$ or more since 1999.

They are continuing to evaluate materials from renewable resources such as a plastic made from corn and natural fabrics for vehicle interiors. For example, they have introduced soy oil-based polyurethane foam for use in passenger seats in the Corolla and the Lexus RX.

Currently, their End f Life Vehicle (ELV) recycling/recovery rate is over 90\% with a goal of 95\% ELV recycling/recovery by 2015. The use of metal returnable shipping containers in their parts distribution network has saved over 30 million pounds of wood, 10 million pounds of cardboard and $\$ 20$ million in packaging costs since the program launched in 2003.

They have extensive programs to reduce the use of substances of concern (SOCs) in vehicles, minimize undesirable emissions from manufacturing operations, and further improve vehicle emission standards.

\section{Sustainable Infrastructure}

Since 2007, Toyota has hosted the Meeting of the Minds summit. The summit "is an invitation only leadership summit. It brings together 130+ policy-makers, opinion-shapers and thought-leaders from commercial, non-profit and public sector organizations (6)."

Toyota offers three different major programs that provide teachers with grants and students with scholarships, as well as, sponsoring a number of nonprofit educational organizations. "In 2007, [Toyota Motor Sales, U. S. A., Inc.] contributed $\$ 57$ million to U.S. philanthropic programs (7)”

\section{Social Work}

Toyota places great importance on their social responsibilities to the communities in which they operate, the consumers they serve, and all of their stakeholders. Toyota breaks these social responsibilities into three categories: (1) initiatives toward improving traffic safety, (2) social contribution, and (3) communication with society. These topics are outlined below. Some of the following practices appear to be nothing more than good business practices, but Toyota clearly goes beyond typical good business practices to train the world to become more sustainable. 


\section{Initiatives Improving Traffic Safety}

Toyota believes that in order for automobiles to keep developing as a means of transportation, the negative effects on the environment must be minimized, along with traffic accidents and traffic congestion.

In August 2006, Toyota announced its Integrated Safety Management Concept, an expression of the direction of Toyota's technology development. Under this integrated Management, information detected by various sensors, including information on the driver's physical condition, the vehicle's performance, and the traffic environment, is processed by an onboard computer which activates the active safety system to determine the optimal support at all stages of vehicle operation to give the driver in order to prevent a dangerous situation from occurring (8).

Toyota has developed a "navigation-linked brake assist system" which alerts the driver of upcoming stop signs both visually and aurally. The system is based on two lanes in a few cities in Japan, and they are planning on gradually expanding the coverage.

They have also developed advances in the driver monitoring system. For example, it can monitor the driver's eyelids as well as the direction of the driver's face. It calculates the how open the eyelids are by detecting the upper and lower eyelids. In order to protect pedestrians in

an accident, Toyota has adopted "impact-absorbing structures in the hood, cowl, fenders, and bumpers." These are only a few of the developments Toyota has made in order to make driving safer for their consumers.

\section{Social Contribution}

Toyota is striving to be a good corporate citizen and as a result they are involved in various social contribution activities.

Toyota also has a number of environmental initiatives, which include: (1) Anti-desertification Initiative in China, (2) Assistance for Rainforest Restoration in the Philippines, (3) Launching an Initiative to Construct a Model Forest Restoration Program in Japan, (4) The Forest of Toyota, (5) Toyota Environmental Activities Grant Program, and (6) Employees Discuss and Draw Up Fundamental Principles at the Toyota Shirakawa-Go Eco-Institute. Toyota also has a plethora of initiatives for traffic safety, education, support for culture and the arts, and community care.

Toyota maintains the same policies and practices globally as they do in the United States. In Spain, Toyota has supported planting trees along the riverbanks of two large rivers that drain the Iberian Peninsula: the Tajo and Guadiana. In New Zealand, Toyota is working with non-governmental organizations to protect Maui's Dolphin, which is distinctive for its small size and rounded dorsal fin. In Malaysia, they are educating children on road safety in an attempt to eliminate traffic accidents. Road safety is one of the biggest social concerns in Pakistan, with the number of vehicles increasing by $10 \%$ per year. So Toyota has developed a fun way to teach road safety to children there. They are providing support for financially disadvantaged children to continue their education in China. In Indonesia, they are supporting the local community by carrying out tree-planting activities. These are just a few of the socially responsible activities that Toyota supports globally.

\section{Communication with Society}

Toyota is a part of the World Business Council for Sustainable Development. "Headquartered in Geneva, the World Business Council for Sustainable Development (WBCSD) is a coalition of 200 international companies united by a shared commitment to sustainable development... The WBCSD has established four focus areas: 'Energy and Climate,' 'Development,' 'Business Role and Ecosystems,' and makes policy proposals [there under]." Toyota also held the Classic Car Festival at MEGA WEB IN Odaiba, Tokyo. It was held there for the first time in commemorate Toyota's $70^{\text {th }}$ anniversary. Toyota believes that it is important to meet and discuss issues with its wide range of stakeholders, and since 2001 has hosted the Toyota Stakeholder Dialogue every year. 


\section{Competitive Comparison}

Subaru and Honda are two of Toyota's biggest competitors, so to better understand Toyota's actions, it is imperative to compare them to their competitors. The sustainable information from Honda and Subaru will be summarized in this section.

\section{Subaru (9)}

\section{Environmental Policy}

Subaru of America (SOA), Inc. is a wholly-owned subsidiary of Fuji Heavy Industries Ltd of Japan. Headquartered in Cherry Hill, New Jersey, the company markets and distributes all-wheel drive Subaru vehicles, parts and accessories. SOA understands its responsibility to the global environment, society at large, their customers, their distribution network and their employees. As they conduct their business operations into the future, they commit to establish and maintain an effective environmental management system that extends further than just meeting the stated environmental laws and regulations, and that encompasses the integration of sound environmental practices in all of their business decisions.

\section{Subaru's Environmental Commitments}

1. Comply with all environmental laws and regulations and other requirements related to our business activities.

2. Implement effective pollution prevention systems that protect our air, land and water.

3. Conserve natural resources, by reducing, reusing and recycling materials.

4. Continuous improvement of our Environmental Management System (EMS).

5. Create employee awareness and commitment to SOA's Environmental Philosophy and Policy.

6. Work with SOA's business partners to improve their operational impact on the environment.

\section{The Subaru Clean Plant}

The Subaru plant was the first auto assembly plant to achieve zero landfill status - nothing from its manufacturing efforts goes into a landfill. It's all reused and recycled. Each year, SIA actively recycles $99.3 \%$ of excess/leftover steel, plastic, wood, paper, glass, and other materials. The remaining $0.7 \%$ is shipped to the city of Indianapolis and incinerated to help generate steam. In 2006, SIA recycled 11,411 tons of scrap steel, 1,537 tons of cardboard and paper, and 963 tons of wood. That's equal to conserving 31,040 mature trees, 31,572 cubic yards of landfill space, 711,631 gallons of oil, and 10,759,000 gallons of water.

\section{Firsts In The Industry Achieved By The Clean Plant}

1. $\quad$ First auto assembly plant in the U.S. to be smoke free.

2. First auto assembly plant in the U.S. to be ISO 14001 Certified.

3. First auto assembly plant in the U.S. with an on-site solvent recovery system that produces dry still bottoms.

4. First U.S. automotive assembly plant to be designated a wildlife habitat. Deer, coyotes, beavers, blue herons, geese, and other animals live there in peaceful coexistence with the Subaru plant. It's our commitment to leave as small a footprint as possible, delivering real-world benefits that everyone can enjoy.

5. Awarded the U.S. EPA's Gold Achievement Award as a top achiever in the agency's WasteWise program to reduce waste and improve recycling.

\section{Vehicles}

Subaru offers the most fuel efficient All-Wheel Drive vehicle lineup in America. Since 2003, Subaru has offered Partial Zero Emissions Vehicle (PZEV) certified Legacy, Outback, and Forester models for sale anywhere in 
the United States. Subaru PZEV vehicles meet California's Super-Ultra-Low-Emission Vehicle exhaust emission standard. Gasoline vehicles meeting PZEV emissions standards can have even lower emissions than hybrid or alternative fuel vehicles. Subaru PZEV vehicles are also U.S. Environmental Protection Agency (EPA) Certified SmartWay Vehicles and are honored in the EPA's Green Vehicle Guide.

\section{Green Suppliers}

Subaru also has a list of guidelines that was revised in 2008, which their suppliers must meet. This ensures that even the companies supplying parts to Subaru are environmentally friendly.

\section{Honda (10)}

\section{Initiatives and Awards}

Hydrogen Home Energy Station" Honda has established an experimental Home Energy Station (HES) that generates hydrogen from natural gas for use in fuel cell vehicles while supplying electricity and hot water to the home. The new HES system that has been jointly developed with strategic fuel cell partner Plug Power is located on the grounds of Honda R\&D Americas in Torrance, California, and is intended to demonstrate and evaluate hydrogen productions, storage and fueling as part of ongoing research in hydrogen energy sources. Honda is researching ways to improve the energy efficiency of the hydrogen fuel production process and vehicle efficiency. The new HES system produces enough hydrogen each day to refill the tank of a Honda FCX hydrogen fuel cell electric vehicle, a process that takes just a few minutes. The system consists of the following major processes and components:

1. Reformer to extract hydrogen from natural gas

2. Fuel cell unit to provide electric power that utilizes some of the extracted hydrogen

3. $\quad$ Refiner to purify the hydrogen

4. Compressor for pressurizing the extracted hydrogen

5. High-pressure tank unit to store the hydrogen for refueling

6. Solar panels

Honda Engineering, a Honda subsidiary, developed the solar cell panels included in the HES system. Those next-generation solar cell panels feature a light-absorbing layer formed by a compound made of copper, indium, gallium and selenium (CIGS), which lowers the amount of electricity required for production of solar cells compared to ordinary silicone-crystal type solar cells. Similarly, the new Honda-developed electrolysis unit included in the HES system is a compact unit that achieves higher efficiency generating hydrogen from water by using a new ruthenium-based catalyst. The result of these new Honda technologies is increased efficiency in producing hydrogen from renewable energy.

\section{Green Factories}

All major Honda plants worldwide already meet the toughest international environmental management standards (ISO 1400), covering a host of environmental areas, such as waste disposal, water treatment and energy use. Honda's philosophies on the three R's:

Reduce: When it comes to improving operations, Honda listens to the people who know best - their employees. Honda associates have provided many of the recommendations now in place that have helped reduce up to 58 percent of their waste.

Reuse: Raw materials used in Honda's manufacturing process are not just sent to landfills - they are reused in the most efficient ways possible. For example, leftover raw steel from stamping is used for engine and brake components.

Recycle: Recycling improves the bottom line while healing the skyline. Honda has annually received up to $\$ 1.2$ million in revenue from recycling paper, cardboard and plastic from their facilities. They have also focused 
on the use of returnable shipping containers and the development of emissions-reducing door - and truck-sealer materials.

\section{Vehicles}

Four Honda vehicles have earned recognition from the American Council for an Energy Efficient Economy (ACEEE) as the "greenest vehicles" of 2006. In their $9^{\text {th }}$ annual Green Book: The Environmental Guide to Cars and Truck ranking of environmentally responsible vehicles, two Honda models tied for the top spot on its list of "Greenest Vehicles of 2006: the natural gas-powered Civic GX and the Insight hybrid, Honda Civic and Civic Hybrid were also among the top twelve greenest vehicles of the year. This was the sixth year in a row that a Honda vehicle received the number one ranking in this study, and the fifth consecutive year that Honda vehicles held at least 4 of the top 12 positions.

\section{Additional Awards}

1. Insight tops Edmunds.com list of "Top 10 Most Fuel-Efficient Cars for 2005."

2. Honda Insight earns Highest EPA Fuel Economy Rating in 2005.

3. 2006 Accord Hybrid Sedan wins Kiplinger's Best Fuel Economy in the $\$ 30,000-\$ 45,000$ category.

4. 2006 Insight garners Best Fuel Economy honors from Kiplinger's.

5. 2008 Civic GX is named "America's Greenest Car" by the American Council for an Energy-Efficient Economy (ACEEE).

6. Civic Hybrid is third on the Edmunds.com list of "Top 10 Most Fuel-Efficient Cars for 2006.

7. Civic Hybrid and Fit make the Edmunds.com list of "Top 10 Most Fuel-Efficient Cars for 2007.

\section{SUMMARY}

As evidence of Toyota's efforts over the years, they have attempted to be highly competitive with regard to the sustainability. Toyota focused on improving their competitiveness in the area of leadership, organizational structure and operational changes.

Toyota has published its $13^{\text {th }}$ annual Sustainability Report reviewing its environmental and social activities for 2009. Number one on its list of topics is what Toyota calls "the quality issue." The report addresses both the events of last year and looks to the future by emphasizing the proper disclosure of information about quality-related issues to its dealers and to the public. The report also re-states Toyota's environmental initiatives, such as reducing $\mathrm{CO} 2$ emissions, and confirms Toyota's commitment to social issues, including those in emerging countries. Further investigation will be done to see the progress that Toyota has made to remain competitive relative to sustainability (11).

\section{AUTHOR INFORMATION}

Dean R. Manna Ph.D. has consulted for private industry, government, and the public sector for thirty years in the areas of sales, management, customer relations, and marketing. He has published a complete instructional manual on Client Centered Selling for use in the classroom and corporate training. His teaching specialty is in the area of Professional Selling both at the undergraduate and graduate level. Dr. Manna's primary research interest is on Emotional Intelligence and its effects on productivity and morale in the public and private sector. Dr. Manna was a past president of the Pittsburgh Chapter of the American Marketing Association. He holds his undergraduate degree in Business from Gannon University, an MBA from the University of Cincinnati, and his Ph.D. from the University of Pittsburgh. He is a University Professor of Marketing and Department Head of the Marketing Department in the School of Business at Robert Morris University.

Gayle Marco, Ph.D. received her Ph.D. degree from the University of Pittsburgh. (Major: Marketing Education and Vocational Education) Her research interests include various areas of consumer decision making, buyer behavior and the various areas of sustainability. She has consulted for numerous companies in the Pittsburgh area. The consulting areas include product repositioning, market development for new products, needs assessments, and market plan 
development. Professor Marco integrates "real" marketing projects for area businesses in her teaching at the undergraduate and graduate level. She has published in the Journal of Global Business, The Journal of American Academy of Business, American Journal of Business Education, and Journal of Business Case Studies as well as numerous conference proceedings.

Brittany Khalil is an integrated student at Robert Morris University pursuing a Bachelor Degree in Marketing and a Master Degree in Competitive Intelligence. During my time at Robert Morris University (RMU), I have been a member of the RMU chapter of the American Marketing Association and served as an officer for one year. I created an outline for a sustainable committee for RMU, which was presented at the sustainable conference on campus. I have also made the Dean's List the past two years.

Sara Meier is a senior marketing major at Robert Morris University in Moon Township, PA. Over the last four years at RMU, she has been involved with the American Marketing Association, the National Society for Collegiate Scholars, RMU Women's Tennis Team, honors program Student Advisory Council and as a Freshmen Mentor. During the summer of 2009, Sara was a student at The Washington Center in Washington, DC, which is a non-profit academic internship program and had a marketing internship at Book Hill Partners, a small PR/lobbying firm in DC while also taking a class about International Business in the Middle East. She was inducted into the Beta Gamma Sigma International Honor Society and a nominee for the 2010 RMU Woman of Achievement Award. She studied abroad in Rome, Italy during the Fall 2009 semester.

\section{REFERENCES}

1. Agency, U.E. (2010, November 17). Sustainability: Basic Information. Retrieved December 21, 2010, from EPA: http://www.epa.gov/sustainability/basicinfo.htm\#sustainability

2. Worldometers: Cars Produced This Year (2009). Retrieved December 20, 2010 from Worldometers: http://www.worldometers.info/cars/

3. $\quad$ http://www.toyota.com/about/our_business/our_history/u.s. history/1950s_\&_1960s.html

4. $\quad$ http://www.toyota.com/about/our business/our history/u.s. history/1970s \& 1980s.html

5. http://www.Toyota.com/about/environment/operations/

6. http://www.meetingoftheminds2009.com/

7. $\quad$ http://www.aredorbit.com/news/display/?id=1656718

8. Sustainability Report 2008

9. http://www.subaru.com/company/environmental-policy.html

10. http://corporate.honda.com/environment/

11. http://inspiredeconomist.com/2010/10/04/CSR_minute_Toyota_sustainable_report_addresses the quality issues/II 